\title{
Size-resolved source apportionment of ambient particles by positive matrix factorization at Gosan background site in East Asia
}

\author{
J. S. Han ${ }^{1}$, K. J. Moon ${ }^{1}$, S. J. Lee ${ }^{1}$, Y. J. Kim ${ }^{2}$, S. Y. Ryu' ${ }^{2}$, S. S. Cliff ${ }^{3}$, and S. M. Yi ${ }^{4}$ \\ ${ }^{1}$ Department of Air Quality Research, National Institute of Environmental Research, Environmental Research Complex, \\ Kyeongseo-dong, Seo-gu, Incheon, 404-170, Republic of Korea \\ ${ }^{2}$ ADvanced Environmental Monitoring Research Center (ADEMRC) at Gwangju Institute of Science and Technology \\ (GIST), Oryong-dong, Buk-gu, Gwangju, 500-712, Republic of Korea \\ ${ }^{3}$ The DELTA Group (DAS), University of California, Davis, CA, USA \\ ${ }^{4}$ Department of Environmental Health, Seoul National University, Yongun-dong, Jongno-gu, Seoul, 110-799, Republic of \\ Korea
}

Received: 24 March 2005 - Published in Atmos. Chem. Phys. Discuss.: 22 July 2005

Revised: 20 October 2005 - Accepted: 16 December 2005 - Published: 27 January 2006

\begin{abstract}
Size- and time-resolved aerosol samples were collected using an eight-stage Davis rotating unit for monitoring (DRUM) sampler from 29 March to 29 May in 2002 at Gosan, Jeju Island, Korea, which is one of the representative background sites in East Asia. These samples were analyzed using synchrotron X-ray fluorescence for 3-h average concentrations of 19 elements consisting of $\mathrm{S}, \mathrm{Si}, \mathrm{Al}$, $\mathrm{Fe}, \mathrm{Ca}, \mathrm{Cl}, \mathrm{Cu}, \mathrm{Zn}, \mathrm{Ti}, \mathrm{K}, \mathrm{Mn}, \mathrm{Pb}, \mathrm{Ni}, \mathrm{V}, \mathrm{Se}, \mathrm{As}, \mathrm{Rb}, \mathrm{Cr}$, $\mathrm{Br}$. The size-resolved data sets were then analyzed using the positive matrix factorization (PMF) technique in order to identify possible sources and estimate their contribution to particulate matter mass. PMF analysis uses the uncertainty of the measured data to provide an optimal weighting. Fifteen sources were resolved in eight size ranges $(0.07 \sim 12 \mu \mathrm{m})$ and included continental soil, local soil, sea salt, biomass/biofuel burning, coal combustion, oil heating furnace, residual oil fired boiler, municipal incineration, nonferrous metal source, ferrous metal source, gasoline vehicle, diesel vehicle, copper smelter and volcanic emission. PMF analysis of size-resolved source contributions showed that natural sources represented by local soil, sea salt and continental soil contributed about $79 \%$ to the predicted primary particulate matter (PM) mass in the coarse size range $(1.15 \sim 12 \mu \mathrm{m})$. On the other hand, anthropogenic sources such as coal combustion and biomass/biofuel burning contributed about $60 \%$ in the fine size range $(0.56 \sim 2.5 \mu \mathrm{m})$. The diesel vehicle source contributed the most in the ultra-fine size range $(0.07 \sim 0.56 \mu \mathrm{m})$ and was responsible for about $52 \%$ of the primary PM mass.
\end{abstract}

Correspondence to: K. J. Moon

(iamiyan@hanmail.net)

\section{Introduction}

Northeast Asia is known to emit a large amount of Asian dust particles and anthropogenic pollutants, due to its high density of industrial activities and increasingly high rate of energy consumption. This region has recently attracted significant attention in terms of atmospheric chemistry and has been the focus of international measurement activities, such as the Asia-Pacific Regional Aerosol Characterization Experiment (ACE-Asia) (Huebert et al., 2003), East Asia/North Pacific Regional Experiment (APARE) (Carmichael et al., 1997), Transport and Chemical Evolution over Pacific (TRACEP) (Jacob et al., 1999), Pacific Exploratory Mission-West (PEM-WEST) (Hoell et al., 1991), being a subproject of the International Global Atmospheric Chemistry (IGAC) Program, and the Atmospheric Brown Cloud (ABC) program (Ramanathan et al., 2003) supported by UNEP. Moreover, as the Korean peninsula is located in the middle of the westerly wind latitude region of northeast Asia, many studies on the influence of long-range transport (LRT) have been performed in this region.

It is commonly necessary to identify aerosol sources and estimate their influence on ambient PM concentration in order to formulate effective control strategies for ambient particulate matter. Measures of source apportionment have been derived from various statistical methods to achieve these goals, and utilize method such as chemical mass balance (CMB), factor analysis, and those based on multiple linear regression. In particular, receptor modeling using aerosol chemical composition data is a reliable method that can provide information on aerosol sources. However, the commonly used multivariate receptor models such as principal component analysis (PCA) have several drawbacks. The

(C) 2006 Author(s). This work is licensed under a Creative Commons License. 


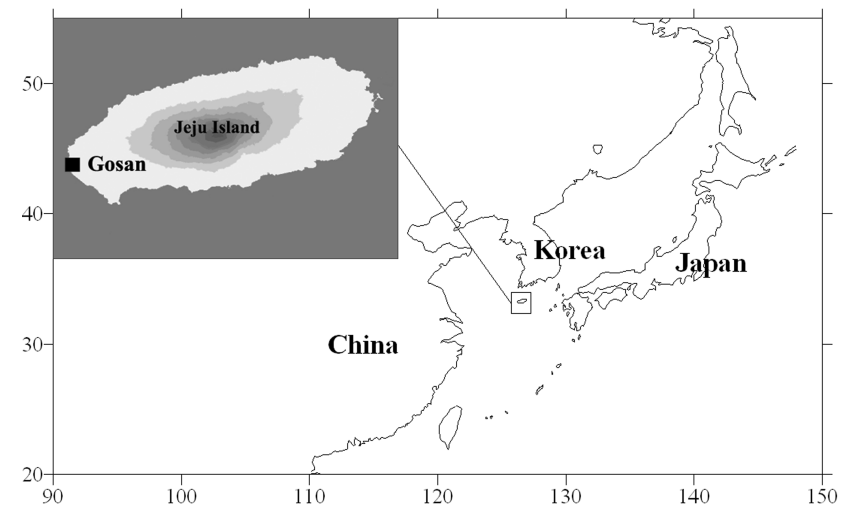

Fig. 1. Location of the Gosan sampling site.

factors used in PCA are not always physically realistic, as negative values may appear among factor loadings and factor scores. Additionally, PCA results do not represent a minimum variance solution because the method is based on incorrect weighting by assuming unrealistic standard deviations for the variables in the data matrix. Furthermore, PCA is incapable of handling missing and below-detection-limit data often observed in environmental measurements.

A newly developed Positive Matrix Factorization (PMF) method (Paatero and Tapper, 1994) overcomes the weak points of the previous receptor model. It introduces a weighting scheme taking into account errors of the data points, which are used as point-by-point weights. Adjustment of the corresponding error estimates also allows it to handle missing and below-detection-limit data. Moreover, non-negative constraints are implemented in order to obtain more physically explainable factors (Paatero, 1998). PMF has been successfully applied to the analysis of ambient aerosol data in many urban, rural and remote areas (Begum et al., 2004; Kim et al., 2003; Polissar et al., 2001; Song et al., 2001).

Most previous studies examined the contributions of emission sources to $\mathrm{PM}_{2.5}$ and $\mathrm{PM}_{10}$ mass using PMF (Kim et al., 2003; Begum et al., 2004; Ramadan et al., 2000). Composition of ambient aerosol varies with size, even in the fine size range $(<2.5 \mu \mathrm{m})$, and is dependent on the type of anthropogenic source. Therefore, more size-segregated composition data are needed in the fine size range in order to improve the accuracy of anthropogenic source apportionment. From this point of view, PMF analysis has been performed in this study on the Gosan aerosol data collected by a DRUM sampler in order to obtain a better estimation of possible aerosol sources and their contributions. The use of a DRUM sampler is advantageous because it can collect fine particles in five stages below $2.5 \mu \mathrm{m}$. Moreover, it is expected that sizesegregated aerosol data collected by a DRUM sampler with a high time resolution will improve the efficiency of PMF analysis.

\section{Sampling and analysis}

Ambient aerosol samples were collected at Gosan, Jeju Island, Korea $\left(33^{\circ} 17^{\prime} \mathrm{N}, 126^{\circ} 10^{\prime} \mathrm{E}, 70 \mathrm{~m}\right.$ a.s.l.) from $29 \mathrm{March}$ to 29 May 2002. Gosan, a representative background site in East Asia, is an ideal location for studying the long-range transport of air pollutants in East Asia (Carmichael et al., 1996; NIER, 1998; Heubert et al., 2003; Han et al., 2004). It has served as a "super site" for the ACE-Asia program (Heubert et al., 2003) and is now a selected "super site" for the ABC project (Ramanathan et al., 2003). During the measurement period, two Asian dust (AD) outbreaks were observed on 8-10 April and 17 April. In this study, aerosol data pertaining to those $\mathrm{AD}$ periods were not subject to $\mathrm{PMF}$ analysis in order to focus on the estimation of anthropogenic aerosol sources.

Size-segregated aerosol samples were collected with an eight-stage Davis Rotating Unit for Monitoring (DRUM) sampling system (Cahill et al., 1985). The DRUM sampler collects size-resolved aerosol samples on Apiezon ${ }^{\mathrm{TM}}$ coated Mylar $^{\mathrm{TM}}$ strips in eight stages, having equivalent aerodynamic cut-off diameters of $0.07,0.26,0.34,0.56,0.75,1.15$, 2.5, 5.0 and $12 \mu \mathrm{m}$. The DRUM sampler was operated continuously during the 61-day sampling period. The DRUM aerosol samples were then analyzed for inorganics (19 elements between aluminum and lead) using synchrotron Xray fluorescence (S-XRF) at the Lawrence Berkeley National Laboratory Advanced Light Source (Perry et al., 2004; Bench et al., 2002). Conditions of S-XRF analysis are summarized in Table 1. Data reduction was performed offline using a well-accepted international XRF code, AXIL to generate the elemental profiles in 3-h temporal resolution. A detailed description of the sampling and analysis methods is provided by Cahill et al. (1993).

\section{Data analysis by PMF}

The Positive Matrix Factorization (PMF) method was developed by Paatero (Paatero and Tapper, 1993) to provide a flexible modeling approach that effectively uses the information in the data. In PMF, the data matrix $\mathbf{X}$ of dimension $\mathrm{n}$ rows and $\mathrm{m}$ columns, where $n$ and $m$ are the number of samples and species, respectively, can be factorized into two matrices, namely $\mathbf{G}(n \times p)$ and $\mathbf{F}(p \times m)$, and a residual component $\mathbf{E}$, where $p$ represents the number of factors extracted:

$\mathbf{X}=\mathbf{G F}+\mathbf{E}$

$\mathbf{G}$ is the source contribution matrix with $p$ sources, and $\mathbf{F}$ a source profile matrix. PMF provides a solution that minimizes an object function, $Q$, based upon the uncertainty for each observation (Paatero, 2000), which is defined as:

$$
Q=\sum_{i=1}^{n} \sum_{j=1}^{m}\left(\frac{e_{i j}}{s_{i j}}\right)^{2},
$$


Table 1. XRF analysis conditions*.

\begin{tabular}{|c|c|c|c|c|c|c|}
\hline $\begin{array}{l}\text { Photon Energy Range } \\
\qquad(\mathrm{keV})\end{array}$ & Monochromator & $\begin{array}{l}\text { Photon Flux } \\
\text { (Photons/s) }\end{array}$ & $\begin{array}{l}\text { Spectral Resolution } \\
(E / \Delta E)\end{array}$ & $\begin{array}{l}\text { Spatial Resolution } \\
\text { (mm) }\end{array}$ & Detectors & $\begin{array}{l}\text { Sensitivity of } \\
\text { Detection }\end{array}$ \\
\hline $\begin{array}{c}6-15 \\
\text { (with multiplayer } \\
\text { mirrors) }\end{array}$ & $\begin{array}{l}\text { White light, multiplayer } \\
\text { mirrors in Kirkpatrick-Baez } \\
\text { configuration }\end{array}$ & $\begin{array}{c}3 \times 10^{10} \\
(\text { at } 12.5 \mathrm{keV})\end{array}$ & $\begin{array}{c}25 \\
\text { (at } 12.5 \mathrm{keV})\end{array}$ & $1.0 \times 1.0$ & $\begin{array}{l}\text { Si (Li) x-ray } \\
\text { detector }\end{array}$ & $\sim 0.1 \mathrm{ng} / \mathrm{m}^{-3}$ \\
\hline
\end{tabular}

*: Analyzed by DELTA group in Univ. of California Davis.

$e_{i j}=x_{i j}-\sum_{k=1}^{p} g_{i k} f_{k j}$

where $s_{i j}$ is the uncertainty in the measured data $x_{i j}$. PMF uses a least-squares approach to solve the factor analysis problem with integrating non-negativity constraints into the optimization process, meaning that sources cannot have negative species concentration $\left(f_{k j} \geq 0\right)$ and the sample cannot have a negative source contribution $\left(g_{k i} \geq 0\right)$. The solution of Eq. (2) is obtained using an iterative minimization algorithm, PMF2 (two-way PMF) (Paatero, 2000). PMF2 uses the error of measurement in the data to provide optimum data point scaling, and permits better treatment of missing and belowdetection-limit values. Measurement values, $\mathrm{x}_{i j}$, below the detection limit were replaced by a value of half of the detection limit, and an error corresponding to a relative uncertainty of $100 \%$ was assigned to the original error estimate.

A robust mode of PMF2 was selected for the handling of outlier data in order to degrade the disproportional effect of excessively large data points, and is especially useful in the analysis of environmental data (Paatero, 1996). This can be achieved by introducing a filter function $h_{i j}$ in Eq. (2), the least-squares minimization of $Q$ (Hien et al., 2004):

$Q=\sum_{i=1}^{n} \sum_{j=1}^{m}\left(\frac{e_{i j}}{h_{i j} s_{i j}}\right)^{2}$

where

$h_{i j}=\left\{\begin{array}{cc}1 & \text { if }\left|e_{i j} / s_{i j}\right| \leq \alpha, \\ \left|e_{i j} / s_{i j}\right| / \alpha & \text { otherwise. }\end{array}\right.$

The parameter $\alpha$ is the outlier threshold distance, and the value $\alpha=4$ was chosen in the present study for consistency with Lee et al. (1999) and Hien et al. (2004). The other important parameter of PMF2 is $F_{\text {peak }}$, which can be used to control rotations and yield more physically realistic solutions (Paatero et al., 2002; Begum et al., 2004). In this study, the rotation was controlled by $F_{\text {peak }}$ until an appropriate distribution of the edges is achieved and $\mathbf{G}$ space plotting for PMF modeling reveals the independence of the contributions reducing the rotational ambiguity.

\section{Results and discussions}

4.1 Determination of rotational freedom and the number of sources

The determination of the number of factors in PMF is a critical step. A trial and error method with different numbers of factors is generally employed to obtain optimal conditions with the most physically meaningful results. In addition, the value of $Q$, as defined in Eq. (2), can be used to help determine the optimal number of factors. In this study, information from the scaled residual matrix $(\mathbf{R})$ in PMF is also used to reduce the ambiguity, due to the manual judgment of the number of factors. Each column in matrix $\mathbf{R}\left(r_{i j}=e_{i j} / s_{i j}\right)$ represents the quality of the fitting of each species to the product of GF. For each specific number of factors, two parameters are obtained from $\mathbf{R}$ : $I M$, the maximum individual column mean, and $I S$, the maximum individual column standard deviation (Lee et al., 1999), where

$$
\begin{aligned}
& I M=\max _{j=1 \ldots m}\left(\frac{1}{n} \sum_{i=1}^{n} r_{i j}\right), \\
& I S=\max _{j=1 \ldots m}\left(\sqrt{\frac{1}{n-1} \sum_{i=1}^{n}\left(r_{i j}-\bar{r}_{j}\right)^{2}}\right) .
\end{aligned}
$$

When the number of factors increases to a critical value, $I M$ and $I S$ will drop sharply. Figure 2 shows the variation of $I M$ and $I S$ with differences in the number of factors in eight size ranges. Finally, four to eight factors were found to generate the most reasonable results. A further reduction of the number of factors resulted in a combination of different sources.

After the source profiles were identified without transformation, PMF was run with different $F_{\text {peak }}$ values in order to determine a range within which the objective function $Q$ in Eq. (4) remained relatively constant. The optimal solution should lie within this range (Song et al., 2001; Kim et al., 2003). Negative values of $F_{\text {peak }}$ were used in this study because positive values make the source compositions in matrix F the extreme values, which are either close to zero or unity. Rotmat, a rotational matrix in PMF, is also used to reveal if factors have excessive rotational freedom. The largest element in Rotmat shows the worst case in rotational freedom 

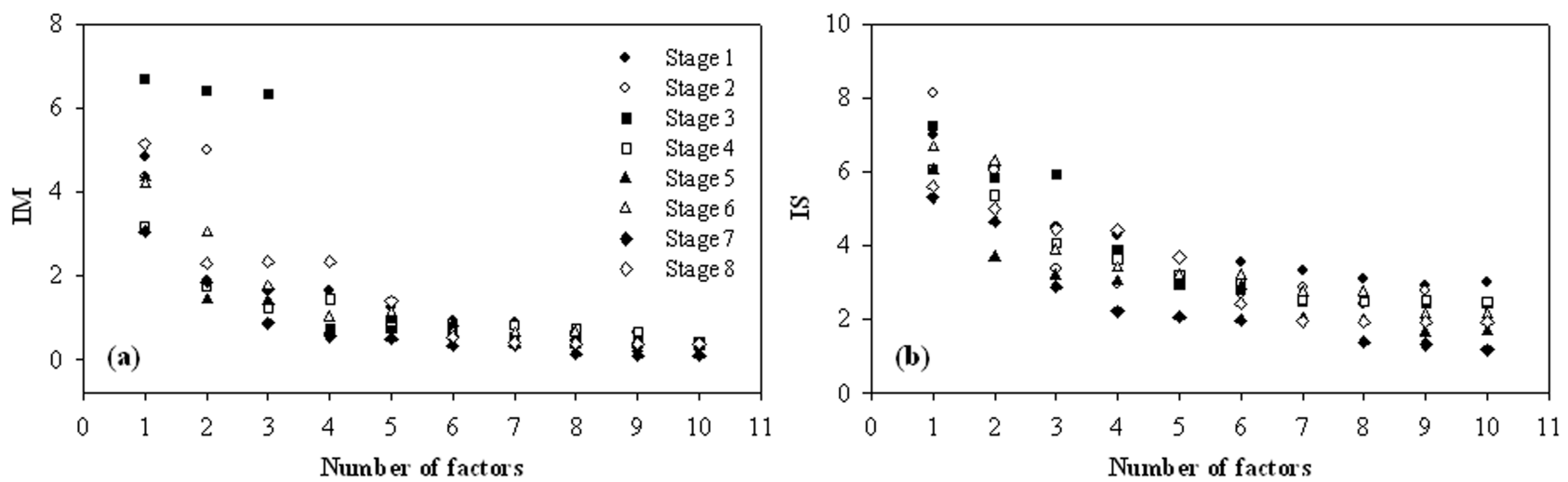

Fig. 2. Determination of the number of factors in eight size ranges by (a) maximum individual column mean (IM), and (b) standard deviation (IS) of standardized residuals.

Table 2. Sources identified in each of the eight size ranges.

\begin{tabular}{|c|c|c|c|c|c|c|c|c|c|c|}
\hline & Source & Major components & Stage $1^{*}$ & Stage $2^{*}$ & Stage $3^{*}$ & Stage $4^{*}$ & Stage $5^{*}$ & Stage $6^{*}$ & Stage $7^{*}$ & Stage $8^{*}$ \\
\hline 1 & Continental soil & $\mathrm{Si}, \mathrm{Al}, \mathrm{Fe}, \mathrm{Ca}, \mathrm{K}, \mathrm{S}, \mathrm{Pb}$ & + & + & + & + & + & + & + & + \\
\hline 2 & Local soil & $\mathrm{Si}, \mathrm{Al}, \mathrm{Fe}, \mathrm{K}, \mathrm{Ti}, \mathrm{Ca}$ & + & + & + & & & & & \\
\hline 3 & Sea salt & $\mathrm{Cl}, \mathrm{S}, \mathrm{K}, \mathrm{Br}$ & + & + & + & & & & & \\
\hline 4 & Biomass/biofuel burning & $\mathrm{S}, \mathrm{K}, \mathrm{Cl}, \mathrm{Si}, \mathrm{Al}$ & & & & + & + & + & + & + \\
\hline 5 & Municipal incineration & $\mathrm{Cl}, \mathrm{Fe}, \mathrm{S}, \mathrm{Al}, \mathrm{Ca}, \mathrm{Zn}, \mathrm{Br}, \mathrm{Pb}$ & + & & & & + & & + & \\
\hline 6 & Coal combustion & $\mathrm{S}, \mathrm{Si}, \mathrm{K}, \mathrm{Zn}, \mathrm{Ca}, \mathrm{Fe}, \mathrm{As}, \mathrm{Se}$ & & & & + & + & + & + & + \\
\hline 7 & Oil heating furnace & $\mathrm{S}, \mathrm{Si}, \mathrm{K}, \mathrm{Ca}, \mathrm{Fe}, \mathrm{V}, \mathrm{Pb}$ & & & + & + & + & & & \\
\hline 8 & Oil fired boiler & $\mathrm{S}, \mathrm{V}, \mathrm{Si}, \mathrm{Ni}$ & & & & & & + & + & + \\
\hline 9 & Gasoline vehicle & $\mathrm{S}, \mathrm{Si}, \mathrm{Ca} \mathrm{Fe}, \mathrm{Zn}, \mathrm{Cl}, \mathrm{K}$ & & & & & + & + & + & + \\
\hline 10 & Diesel vehicle & $\mathrm{Si}, \mathrm{S}, \mathrm{Al}, \mathrm{K}$ & & & & & & & & + \\
\hline 11 & Ferrous metal source-C & $\mathrm{Fe}, \mathrm{Zn}, \mathrm{Cu}, \mathrm{Pb}$ & + & & & & & & & \\
\hline 12 & Nonferrous metal source & $\mathrm{Cu}, \mathrm{S}, \mathrm{Zn}, \mathrm{Fe}, \mathrm{Cr}, \mathrm{Pb}$ & & & & & & & + & + \\
\hline 13 & Ferrous metal source-F & $\mathrm{Fe}, \mathrm{Si}, \mathrm{Al}, \mathrm{K}, \mathrm{Zn}, \mathrm{Mn}$ & & + & + & + & + & & & \\
\hline 14 & Copper smelter & $\mathrm{S}, \mathrm{Si}, \mathrm{K}, \mathrm{Fe}, \mathrm{Zn}, \mathrm{Cu}, \mathrm{As}, \mathrm{Pb}$ & & & & & & + & + & \\
\hline 15 & volcanic emission & $\mathrm{Si}, \mathrm{Al}, \mathrm{S}, \mathrm{K}, \mathrm{Ca}, \mathrm{Fe}, \mathrm{Ti}$ & & & & & + & & & \\
\hline \multicolumn{3}{|c|}{ Number of samples } & 411 & 411 & 411 & 411 & 411 & 335 & 381 & 411 \\
\hline \multicolumn{3}{|c|}{ Number of factor } & 5 & 4 & 5 & 5 & 8 & 6 & 8 & 7 \\
\hline \multicolumn{3}{|c|}{ Q (Chi square) } & 37015 & 31996 & 30992 & 37007 & 12773 & 23331 & 5067 & 12175 \\
\hline \multicolumn{3}{|c|}{ Fpeak } & -0.4 & -0.5 & -0.9 & -0.7 & -0.7 & -0.6 & -0.7 & -0.7 \\
\hline
\end{tabular}

*: stage 1: $5.0 \mu \mathrm{m} \sim$ Inlet, stage 2: $2.5 \sim 5.0 \mu \mathrm{m}$, stage 3: $1.15 \sim 2.5 \mu \mathrm{m}$, stage 4: $0.75 \sim 1.15 \mu \mathrm{m}$, stage 5: $0.56 \sim 0.75 \mu \mathrm{m}$, stage 6: $0.34 \sim 0.56 \mu \mathrm{m}$, stage 7: $0.26 \sim 0.34 \mu \mathrm{m}$, stage 8: $0.07 \sim 0.24 \mu \mathrm{m}$

(Lee et al., 1999). The final acceptable rotations were determined by trial and error and are based on the evaluation of the calculated source profiles in comparison with the true profiles. Figure 3 shows the variation of $Q$ values and the largest element in Rotmat with different $F_{\text {peak values. As a }}$ result, $F_{\text {peak }}$ values of $-0.4 \sim-0.9$ provided the most physically reasonable source profiles in the eight size ranges.

\subsection{Source profiles and temporal variations}

The resolved source profiles from PMF analysis were compared with the known profiles obtained from previous studies (Davis et al., 1981; He et al., 2001; Mamuro et al., 1979a, b; Small et al., 1981; US EPA, 1987; Watson et al., 1979, 1994) in order to identify source type. Source profiles show a very similar shape in the resolved size ranges for the same source. For example, Fig. 4 shows similar profiles of sea salt in stages $1 \sim 3$ and the biomass/biofuel burning source in stages $4 \sim 8$. This similarity of source profiles suggests that PMF has been successfully applied in this study.

Overall, fifteen distinct primary sources were resolved for the ambient aerosols collected at the Gosan site in the spring of 2001, excluding AD periods. Secondary sources were not resolved in this study because the chemical composition data of secondary particles including sulfate, nitrate, ammonium and organic carbon matter was not used in PMF analysis. The parameters and results of PMF analysis are summarized in Table 2. The resolved sources included not only natural sources such as local soil, sea salt, continental 

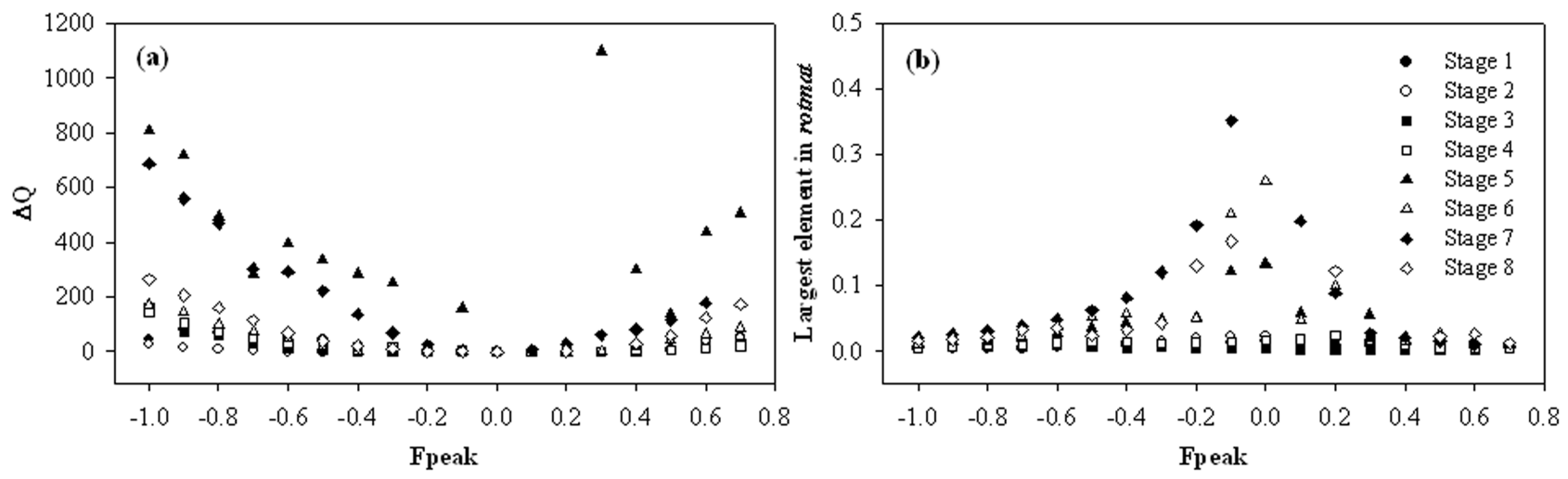

Fig. 3. Determination of the rotational freedom in eight size ranges by (a) Q and (b) largest element in the rotational matrix.
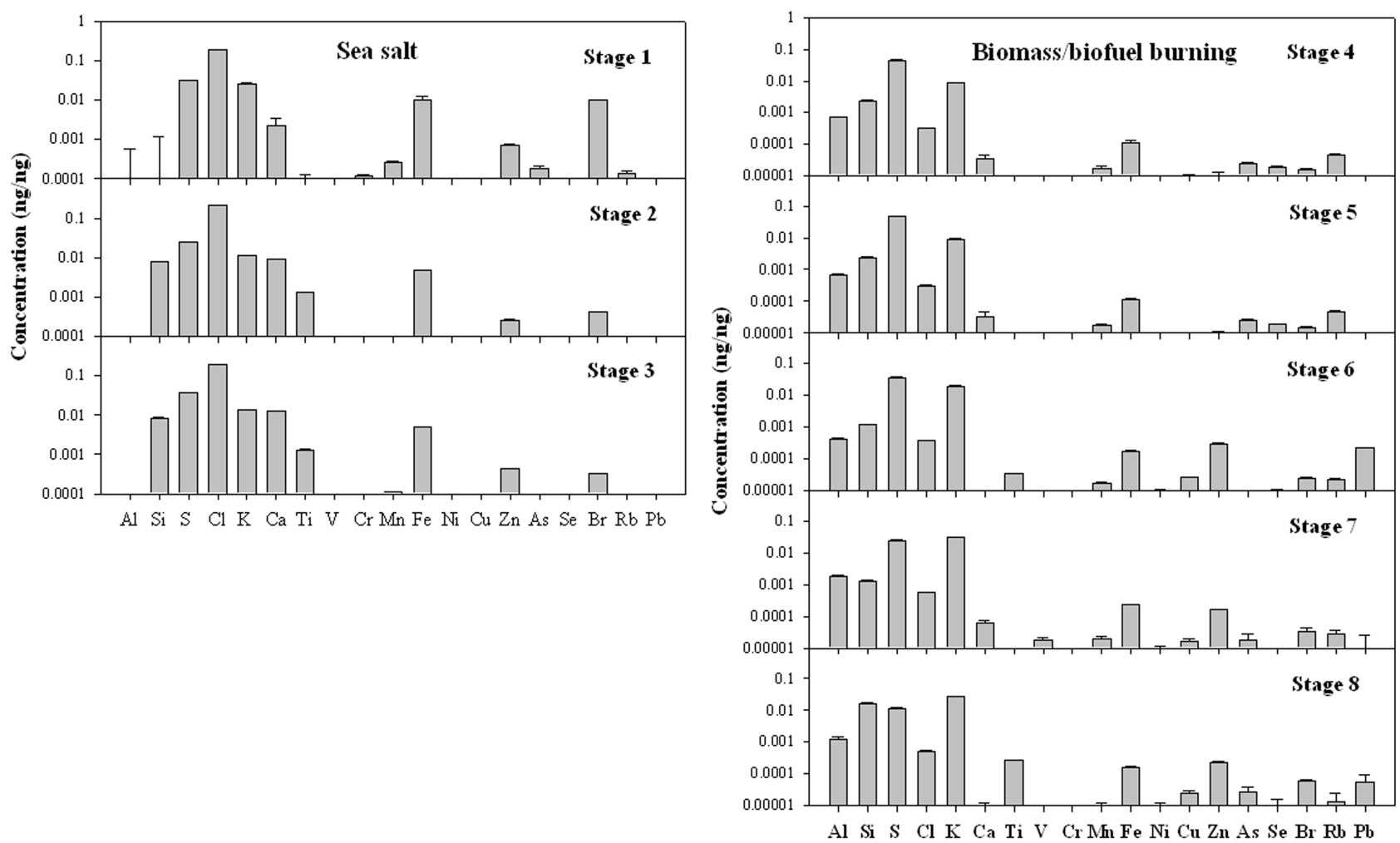

Fig. 4. Source profiles in different size ranges ((a) sea salt, (b) biomass/biofuel burning).

soil and volcanic emission, but also eleven anthropogenic sources such as biomass/biofuel burning, municipal incineration, coal combustion, oil heating furnace, residual oil fired boiler, gasoline vehicle, diesel vehicle, nonferrous and ferrous metal sources and copper smelter. The influence of most anthropogenic sources was observed in the fine size range $(0.07 \sim 1.15 \mu \mathrm{m})$, while the coarse particles $(1.15 \sim 12 \mu \mathrm{m})$ mainly originated from natural sources. It is especially interesting to note that several anthropogenic sources such as gasoline vehicle, diesel vehicle, nonferrous metal source and residual oil combustion were only resolved in the ultra-fine size range $(0.07 \sim 0.75 \mu \mathrm{m})$.
The profiles of fifteen sources were determined by taking an average of similar profiles in different size ranges. The average mass profiles, obtained from PMF analysis, are shown in Fig. 5 with known profiles from previous studies. The resolved source profiles had a chemical composition that was very similar to the corresponding existing source profiles: continental soil (He et al., 2001), soil dust (EPA profile 41340), marine aerosol (Watson, 1979), volcanic emission (Davis et al., 1981), oil heating furnace (Mamoro et al., 1979a), oil fired boiler (EPA 13505), coal combustion (Mamuro et al., 1979a), field burning (EPA profile 42320), municipal incineration (EPA profile 17106), gasoline vehicle 

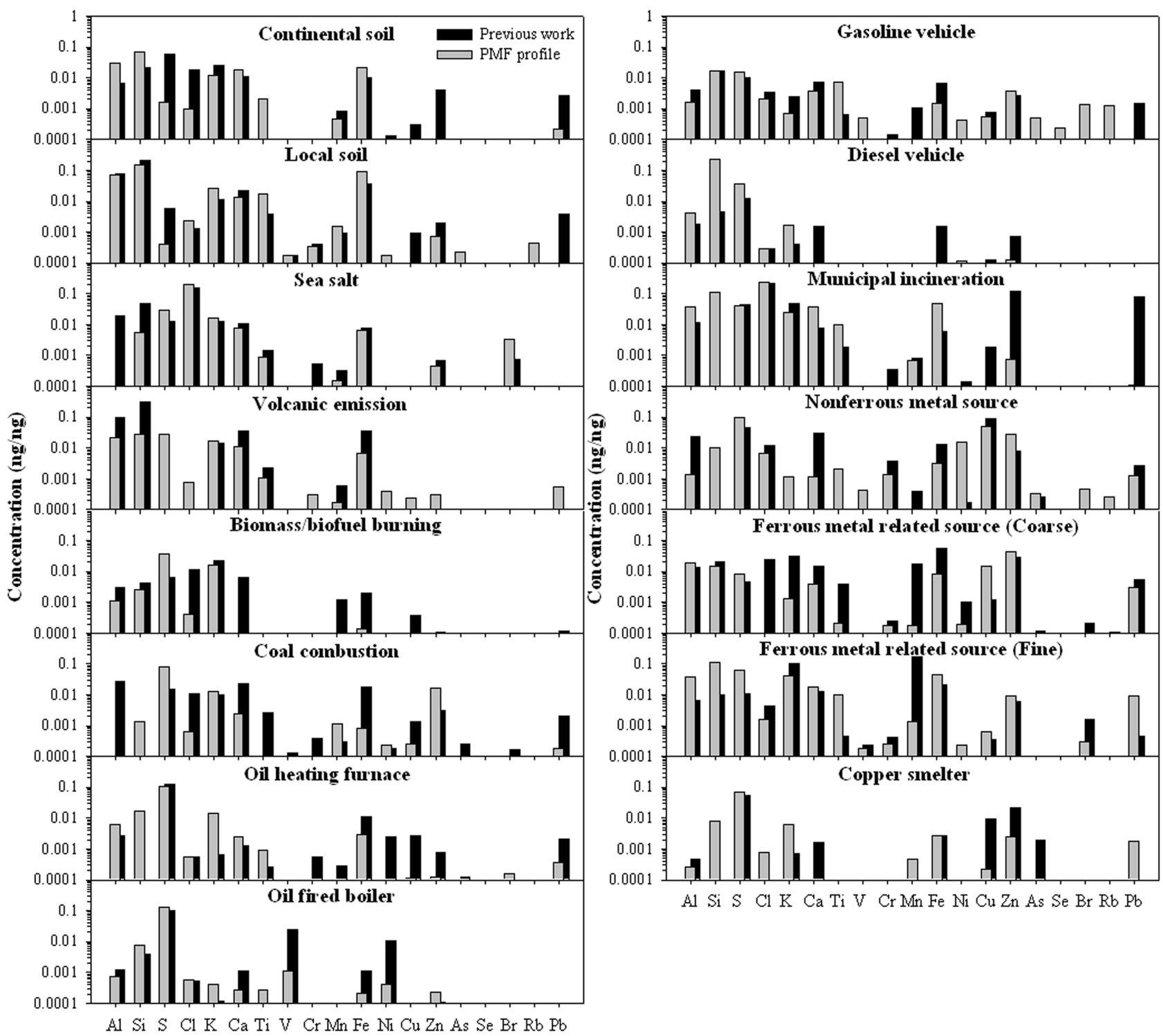

Al $\mathrm{Si} S \mathrm{Cl} \mathrm{K}$ Ca Ti V CrMn Fe $\mathrm{N}_{1} \mathrm{Cu}$ Zn As Se Br Rb Pb

Fig. 5. Average source profiles resolved from size-segregated aerosol samples in this study and corresponding known profiles.

(Watson et al., 1994), diesel vehicle (Watson et al., 1994), nonferrous metal source (Mamuro et al.,1979b), ferrous metal related sources (Watson, 1979; Mamuro et al., 1979b) and copper smelter (Small et al., 1981). At this time, the known source profile and resolved profile did not show exactly the same composition because the source composition is slightly different from each individual emission source, and the known profiles from previous studies are simply averaged source compositions regardless of aerosol size range. Figure 6 represents the corresponding temporal variations of these possible sources. The mass concentration of each source was calculated from the sum of scaled intensity values in the resolved size ranges. Overall, apparent differences in temporal variations of these anthropogenic sources confirm the independence of the estimated source contributions.
The continental soil source usually has a higher concentration of $\mathrm{S}$ and higher ratio of $\mathrm{Ca}$ to $\mathrm{Al}$ than general soil sources influenced by various industrial activities (He et al., 2001). This difference helped to identify these factors into different sources in the PMF analysis. These sources commonly contain the characteristic elements $\mathrm{Si}, \mathrm{Al}, \mathrm{Fe}, \mathrm{Ca}$ and $\mathrm{K}$, and contributed mainly during the first half of the measurement period, especially before and after the AD outbreaks. However, they showed different patterns of temporal variation and size distribution: the continental soil source has lower values and relatively small variations during the entire measurement period, while local soil displayed many sharp peaks over the entire measurement period. In addition, continental soil was observed in all size ranges $(0.07 \sim 12 \mu \mathrm{m})$ while local soil source was only resolved in the coarse size range 

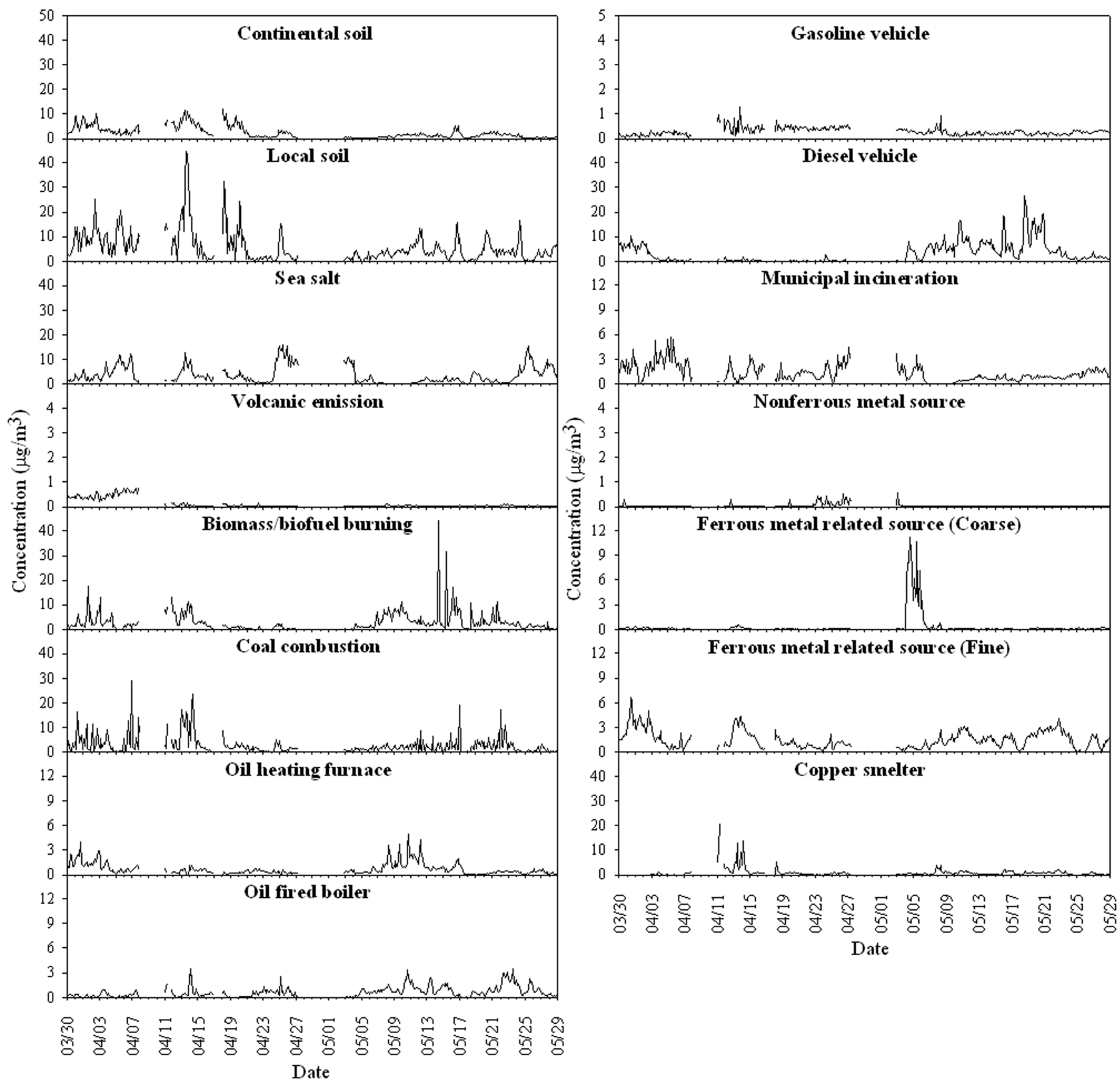

Fig. 6. Temporal variations of total mass concentration using each of the resolved sources during non-AD periods.

$(1.15 \sim 12 \mu \mathrm{m})$. The difference between continental soil and local soil was definitely observed in the backward trajectory analysis using HYSPLIT4 (Draxler, 2004). Figures 7a and $\mathrm{b}$ respectively shows the back trajectories in 3-h intervals observed when the intensities of continental soil and local soil sources were independently higher than other periods as shown in Fig. 6. The trajectories reveal that continental soil was transported from more distant regions including northeastern China than local soil. The sea salt factor characterized by high $\mathrm{Cl}$ and $\mathrm{Br}$ was also resolved in the same coarse size range as the local soil source.
The factors characterized by high $\mathrm{S}$ and $\mathrm{V}$ in the fine size range $(0.07 \sim 2.5 \mu \mathrm{m})$ could be represented by an oil combustion source (Watson, 1997). However, these factors were separated into the two sources, residual oil-fired boiler and industrial oil heating furnace, in order to account for the differences in their chemical composition. In the ultra-fine size range $(0.07 \sim 0.56 \mu \mathrm{m})$, the factor containing the larger amount of $\mathrm{V}$ and Ni represents the influence of the residual oil combustion source (Swietlicki and Krejci, 1996; Sun et al., 2004). The factor characterized by $\mathrm{K}, \mathrm{Ca}$ and $\mathrm{Pb}$ in the relatively large size range $(0.56 \sim 2.5 \mu \mathrm{m})$ represents the 

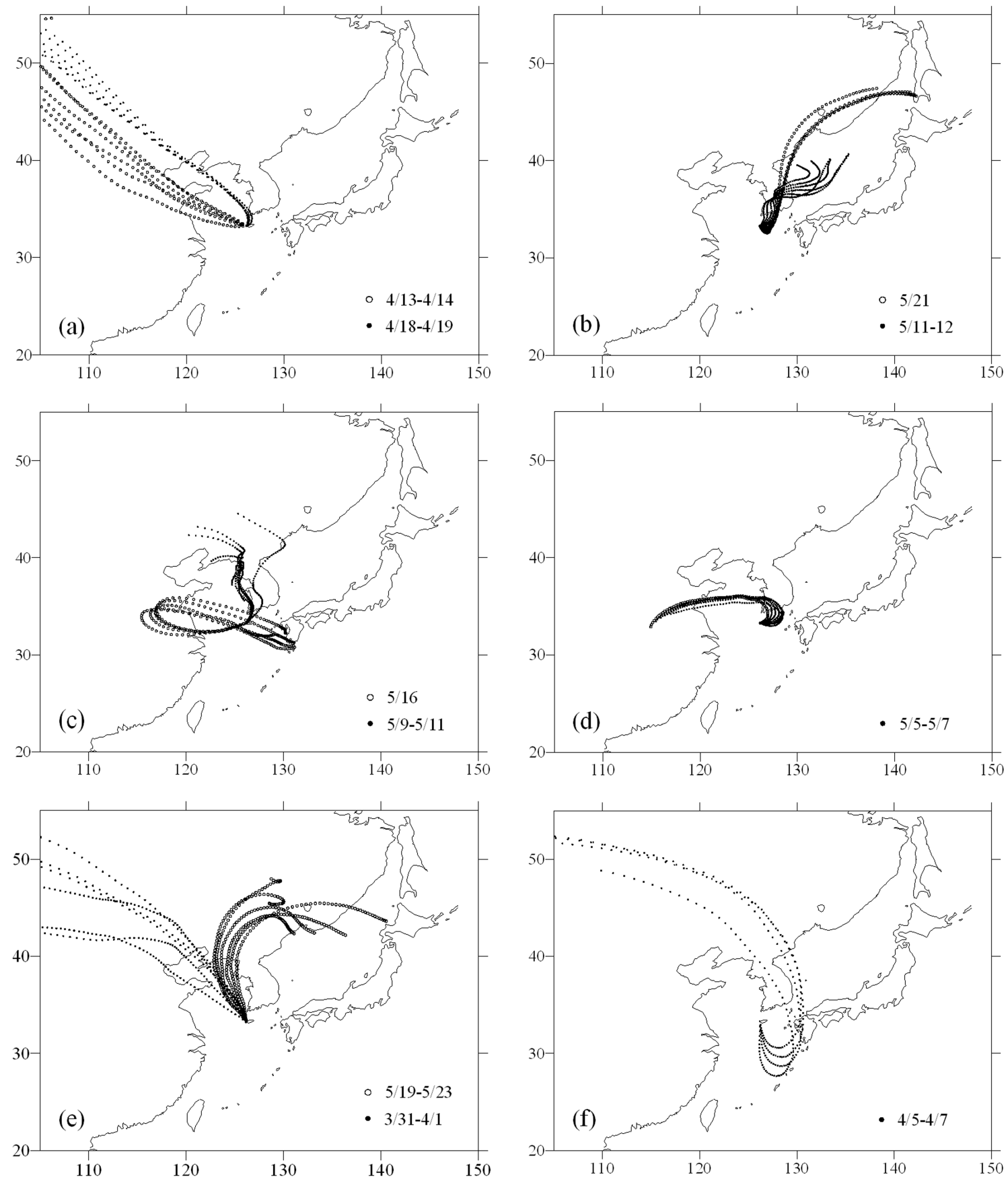

Fig. 7. 3-day backward trajectory analyses of episodic cases ((a) 4/13 14 and 4/18 19, (b) 5/11 12 and 5/21, (c) 5/9 11 and 5/16, (d) 4/5 7, (e) $5 / 5 \sim 7$, (f) $3 / 31 \sim 4 / 1$ and 5/19 23).

industrial oil combustion source (Kang, 2002). The resulting different temporal variations of the two sources support the separate treatment of these sources.

The coal combustion factor shows the presence of $\mathrm{S}$ and As (Cao et al., 2002) in the fine size range $(0.07 \sim 1.15 \mu \mathrm{m})$. The biomass/biofuel burning source was characterized by
K, S and Cl (Song et al., 2001; Cheng et al., 2000) in the same size range. Figure $7 \mathrm{c}$ shows that the backward trajectories from 9 to 11 May and at 16 May 2002 when the intensity of biomass/biofuel burning source was relatively high. The trajectories passed by not only the cultivated regions in central China but also the forests and grassland 


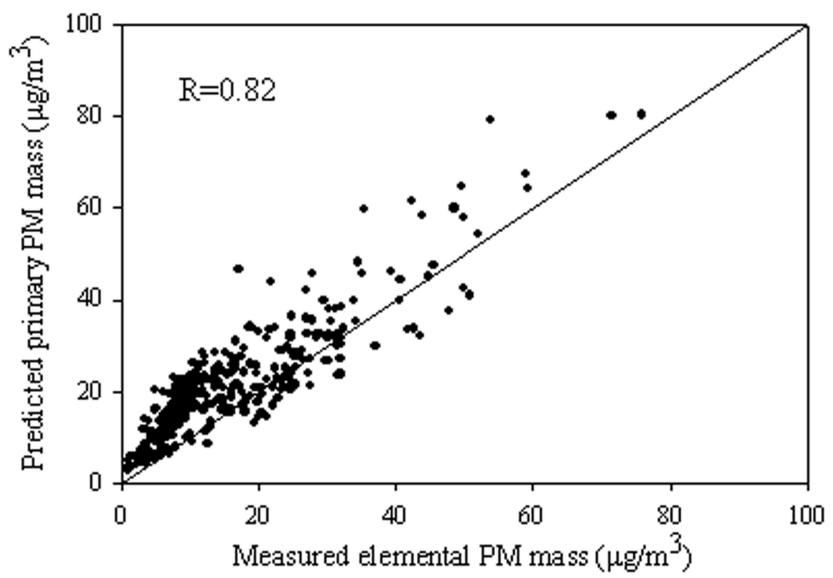

Fig. 8. Comparison of predicted primary PM mass, as determined by PMF analysis, with measured primary PM mass.

located in northeast China and North Korea. Therefore, it is inferred that this source includes field combustion of agricultural residues as well as biofuel combustion. The municipal incineration source was described by $\mathrm{Cl}, \mathrm{S}, \mathrm{Fe}, \mathrm{Br}$ and $\mathrm{Zn}$ (Chueinta et al., 2000; Kang, 2002) in both coarse (5 12 $\mu \mathrm{m})$ and fine size ranges $(0.26 \sim 0.76 \mu \mathrm{m})$.

The motor vehicle sources were classified further into gasoline and diesel vehicle sources. The gasoline vehicle source, represented by $\mathrm{S}, \mathrm{Si}, \mathrm{Ca}, \mathrm{Fe}$ and $\mathrm{Cl}$, was resolved in the fine size range $(0.07 \sim 0.75 \mu \mathrm{m})$. On the other hand, the diesel vehicle source characterized by $\mathrm{Si}, \mathrm{S}, \mathrm{Al}$ and $\mathrm{K}$ was only resolved in the ultra-fine size range $(0.07 \sim 0.26 \mu \mathrm{m})$. The factor associated with $\mathrm{S}, \mathrm{Cu}, \mathrm{Zn}$ and $\mathrm{Pb}$ represents an industrial emission source originating principally from a nonferrous smelter (Lee et al., 1999) and was resolved in the ultra-fine size range $(0.07 \sim 0.34 \mu \mathrm{m})$. The ferrous metal source, mainly loaded with $\mathrm{Fe}, \mathrm{Mn}$ and $\mathrm{Zn}$, was resolved in both coarse $(5 \sim 12 \mu \mathrm{m})$ and fine size $(0.56 \sim 2.5 \mu \mathrm{m})$ ranges. In two size ranges, the ferrous metal related source revealed significantly different source compositions and temporal variations, indicating that the detailed emission source and source region are different in each size range. As shown in Figs. 7d and e, the difference of trajectories when they respectively have high intensities also supports the separation of two ferrous metal related sources. The source in coarse size range was estimated to be transported from southern industrial regions in South Korea while fine aerosol source regions related to the steel industry could be mainly located in major industrial areas in northeastern China. The other metallurgical source, copper smelter, was also resolved in the fine size range $(0.56 \sim 0.75 \mu \mathrm{m})$. Finally the volcanic emission source, containing large amounts of $\mathrm{Al}, \mathrm{Si}, \mathrm{K}, \mathrm{Ca}$ and $\mathrm{Fe}$, was resolved in the fine size range $(0.56 \sim 0.75 \mu \mathrm{m})$ when the trajectories passed around Kyushu Island in which there are several active volcanoes as shown in Fig. 7f.

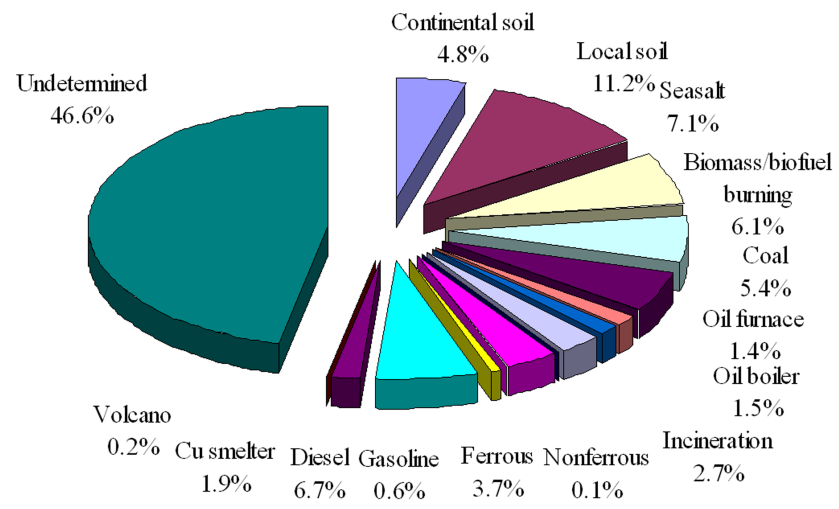

Fig. 9. Average source contributions to the total particle mass concentration.

The effectiveness of PMF analysis was evaluated by a comparison between predicted and measured primary PM mass, as shown in Fig. 8. The measured primary PM mass was obtained from the sum of element mass concentrations measured in eight size ranges, while the predicted primary PM mass was calculated from the sum of scaled source contribution values for each sample. The correlation coefficient between measured and predicted primary PM masses was 0.82 , indicating that the resolved factors effectively accounted for most of the variations in mass concentration of particulate elements.

\subsection{Source contributions}

The average contributions of each source to the measured total PM mass during the non-AD periods are shown in Fig. 9. The total PM $(<12 \mu \mathrm{m})$ mass collected by the DRUM sampler was calculated from the $\mathrm{PM}_{10}$ mass concentration obtained at Gosan ambient air quality monitoring site $\left(33^{\circ} 15^{\prime} \mathrm{N}, 126^{\circ} 12^{\prime} \mathrm{E}\right)$ operated by the Ministry of Environment Korea. $\mathrm{PM}_{10}$ concentration was measured by a $\beta$ ray absorption method, having a detection limit of $2 \mu \mathrm{g} / \mathrm{m}^{3}$ with $1 \mu \mathrm{g} / \mathrm{m}^{3}$ resolution with an interval of $1-\mathrm{h}$. A weighting factor of 1.02 was used in the analysis, and was derived from the previous result that the $\mathrm{PM}_{10}$ mass occupies about $98 \%$ of the $\mathrm{PM}_{12}$ mass on the average at Gosan (Han et al., 2005). On average, the estimated fifteen sources from PMF analysis contributed to about $53 \%$ of the total $\mathrm{PM}_{12}$ mass. At this time, local soil contributed $11 \%$, the largest portion of the $\mathrm{PM}_{12}$ mass, and natural sources including local soil, sea salt and continental soil represented about $23 \%$ of the total $\mathrm{PM}_{12}$ mass. On the other hand, anthropogenic sources contributed to a rather larger portion than natural sources, accounting for $30 \%$ of the total $\mathrm{PM}_{12}$ mass. It is especially interesting to note that the contributions of diesel vehicle, biomass/biofuel burning, coal combustion, ferrous metal source and municipal incineration were large, being equal to $6.7,6.1,5.4,3.0$ and $2.7 \%$, respectively. 

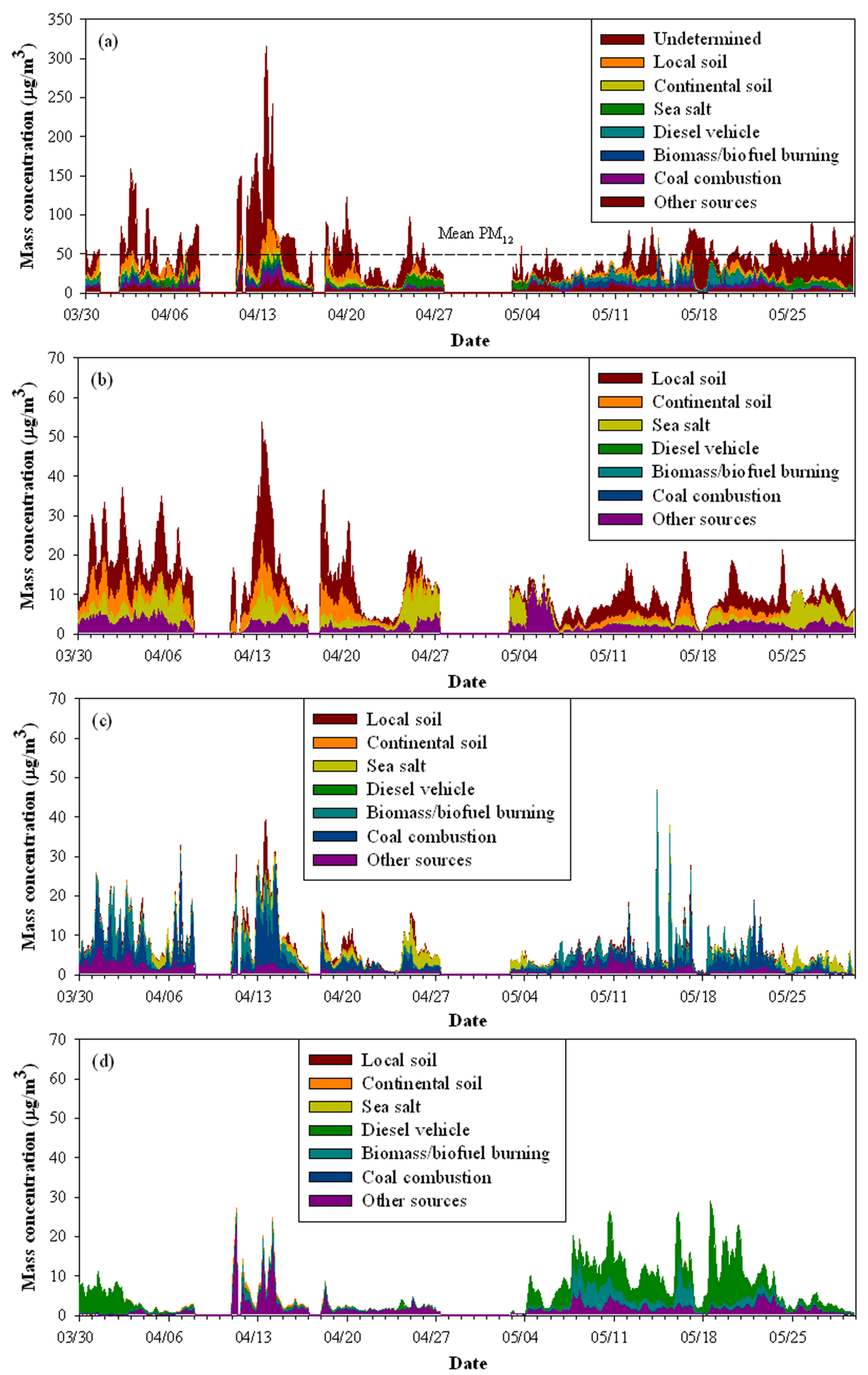

Fig. 10. Temporal variation of PM mass contributed by different source types for (a) total size ranges, (b) the coarse size range $(2.5 \sim 12 \mu \mathrm{m})$, (c) the fine size range $(0.56 \sim 2.5 \mu \mathrm{m})$, and (d) the ultra-fine size range $(0.07 \sim 0.56 \mu \mathrm{m})$. 
Considering the fact that water-soluble ions and carbon components are not included in PMF analysis, the remaining fractions of the total $\mathrm{PM}_{12}$ mass $(47 \%)$ that cannot be described by estimated sources may represent a portion of secondary aerosol components such as ammonium sulfate, ammonium nitrate and secondary organic carbon matter. This agrees considerably with the result of a previous study (KME, 2004) performed at Gosan from 30 March to 11 April 2002 in which the average concentration of organic carbon and secondary ion components, including sulfate, nitrate and ammonium, occupied more than $40 \%$ of the $\mathrm{PM}_{10}$ mass during NAD periods.

Temporal variations of total $\mathrm{PM}_{12}$ mass and estimated source contributions are shown in Fig. 10, where the contribution from each source is accumulated. The results show that many large peaks in total PM mass are produced by the contributions of the resolved sources from PMF analysis. However, the undetermined fraction of $\mathrm{PM}_{12}$ mass reveals rather different temporal variations from those estimated by sources, implying that this fraction originated not from primary emission sources but from secondary particulate matter. In addition, the contributions of various sources reveal different temporal variations correlated with aerosol size range. Source contributions in three different size ranges are assessed separately in Fig. 10. Figure 10b shows that the contribution of natural sources including local soil, sea salt and continental soil was dominant, representing $79 \%$ in the coarse size range $(2.5 \sim 12 \mu \mathrm{m})$. On the other hand, the contribution of anthropogenic sources such as coal combustion, biomass/biofuel burning and diesel vehicle, increased sharply in the fine and ultra-fine size ranges $(0.07 \sim 2.5 \mu \mathrm{m})$, as shown in Figs. 10c and d. Moreover, the contribution of diesel vehicle $(52 \%)$ was observed mainly in the ultrafine size range $(0.07 \sim 0.56 \mu \mathrm{m})$, while the coal combustion source $(33 \%)$ contributed the most in the fine size range $(0.56 \sim 2.5 \mu \mathrm{m})$. The contribution of anthropogenic sources increased to $98 \%$ of the total contribution in the ultra-fine size range $(0.07 \sim 0.56 \mu \mathrm{m})$.

\section{Summary and conclusion}

Size-resolved aerosol chemical composition data collected at Gosan, Jeju Island, Korea were analyzed using the PMF method to estimate the contribution by possible emission sources in various size ranges. Fifteen possible sources were identified over eight size ranges $(0.07 \sim 12 \mu \mathrm{m})$. The result of source identification reveals that natural sources including local soil, sea salt and continental soil, contributed principally in the coarse size range $(1.15 \sim 12 \mu \mathrm{m})$, while the greatest contribution by anthropogenic sources was resolved in the fine size range $(0.07 \sim 1.15 \mu \mathrm{m})$. It is especially interesting to note that several anthropogenic sources such as gasoline vehicle, diesel vehicle, nonferrous metal source and residual oil combustion were only resolved in the ultra-fine size range
$(0.07 \sim 0.75 \mu \mathrm{m})$. The average mass contribution of resolved primary emission sources was about $53 \%$ of the total PM mass. Among them, the natural sources contributed about $23 \%$, and the contribution of other anthropogenic sources, including diesel vehicle, biomass/biofuel burning, coal combustion, ferrous metal furnace and municipal incineration, accounted for about $24 \%$ of the total PM mass. It was also discovered that the contribution of each source varied with respect to particle size range. In the coarse size range $(2.5 \sim 12 \mu \mathrm{m})$, the contribution of natural sources was predominant and attained a level of over $75 \%$. On the other hand, coal combustion and biomass/biofuel burning sources contributed the most in the fine size range $(0.56 \sim 2.5 \mu \mathrm{m})$, accounting for $33 \%$ and $25 \%$ of the total PM mass, respectively. In the ultra-fine size range $(0.07 \sim 0.56 \mu \mathrm{m})$, the diesel vehicle source contributed to more than $50 \%$ of the total PM mass.

PMF analysis has been applied to size-resolved aerosol elemental concentration data obtained by a DRUM sampler at Gosan. Temporal variations of PMF estimated sources were different, suggesting the independence of the resolved sources. These results show that PMF analysis using continuous size-resolved aerosol data is a powerful method for the identification of emission sources from measured ambient aerosol composition data.

Acknowledgements. This work was supported by the project of Ministry of Environment, Korea; "Long Range Transport of Toxic Trace Substances: Identification and Impact Analysis" and in part by the Korea Science and Engineering Foundation (KOSEF) through the Advanced Environmental Monitoring Research Center (ADEMRC) at Gwangju Institute of Science and Technology (GIST). Special recognition goes to K. D. Perry in the University of Utah for helping to analyze the DRUM samples.

Edited by: W. Conant

\section{References}

Begun, B. A., Kim, E., Biswas, S. K., and Hopke, P. K.: Investigation of sources of atmospheric aerosol at urban and semi-urban areas in Bangladehs, Atmos. Environ., 38, 3025-3038, 2004.

Bench, G., Grant, P. G., Ueda, D., Cliff, S. S., Perry, K. D., and Cahill, T. A.: The use of STIM and PESA to measure profiles of aerosol mass and hydrogen content, respectively, across Mylar rotating drum impactor samples, Aerosol Sci. Technol., 36, 642651, 2002.

Cahill, T. A., Goodart, C., Nelson, J. W., Eldred, R. A., Nasstrom, J. S., and Feeny, P. J.: Design and evaluation of the DRUM impactor, Proceedings of the International Symposium on Particulate and Multi-Phase Processes (vol. 2), edited by: Ariman, T. and Nejat, T., Taylor and Francis, Philadelphia, Pa., pp. 319-325, 1985.

Cahill, T. A. and Wakabayashi, P.: Compositional analysis of sizesegregated aerosol samples, in: Measurement Challenges in Atmospheric Chemistry, edited by: Newman, L., Adv. Chem. Ser., 232, 211-228, 1993. 
Cao, L., Tian, W., Ni, B., Zhang, Y., and Wang, P.: Preliminary study of airborne particulate matter in a Beijing sampling station by instrumental neutron activation analysis, Atmos. Environ., 36, 1951-1956, 2002.

Carmichael, G. R., Zhang, Y., Chen, L., Hong, M. S., and Ueda, H.: Seasonal variation of aerosol composition at Cheju Island, Korea, Atmos. Environ., 30, 2407-2416, 1996.

Carmichael, G. R., Hong, M. S., Ueda, H., Chen, L. L., Murano, K., Park, J. K., Lee, H., Kim, Y., Kang, C., and Shim, S.: Aerosol composition at Cheju Island, Korea, J. Geophys. Res., 102(D5), 6047-6061, 1997.

Cheng, Z. L., Lam, K. S., Chan, L. Y., Wang, T., and Cheng, K. K.: Chemical characteristics of aerosols at coastal station in Hong Kong, I. Seasonal variation of major ions, halogens and mineral dusts between 1995 and 1996, Atmos. Environ., 24, 2777-2783, 2000.

Chueinta, W., Hopke, P. K., and Paatero, P.: Investigation of sources of atmospheric aerosol at urban and suburban residential area in Thailand by positive matrix factorization, Atmos. Environ., 34, 3319-3329, 2000.

Gladney, E. S., Small, J. A., Gordon, G. E., and Zoller, W. H.: Composition and Size distribution of In-Stack Particulate Material at a Coal-Fired Power Plant, Atmos. Environ., 10, 1071-1077, 1976.

Draxler, R. ans Hess, G. D.: Description of the HYSPLIT_4 modeling system, NOAA Technical Memorandum ERL ARL-224, 28 pp., Air Resources Lab., Silver Spring, Meryland, 2004.

Han, J. S., Moon, K. J., Ahn, J. Y., Hong, Y. D., Kim, Y. J., Ryu, S. Y., Cliff, S. S., and Cahill, T. A.: Characteristics of ion components and trace elements of fine particles at Gosan, Korea in spring time from 2001 to 2002, Environ. Monit. Assess., 92, 7393, 2004.

Han, J. S., Moon, K. J., Lee, S. J., Kim, J. E., and Kim, Y. J.: Size distribution characteristics of particulate mass and ion components at Gosan, Korea from 2002 to 2003, J. Korean Soc. Atmos. Environ., 21(E1), 23-35, 2005.

He, K., Yang, F., Ma, Y., Zhang, Q., Yao, X., Chan, C. K., Cadle, S., Chan, T., and Mulawa, P.: The characteristics of PM2.5 in Beijing, China, Atmos. Environ., 35, 4959-4970, 2001.

Hien, P. D., Bac, V. T., and Thinh, N. T. H.: PMF receptor modeling of fine and coarse PM10 in air masses governing monsoon conditions in Hanoi, northern Vietnam, Atmos. Environ., 38, 189-201, 2004.

Hoell, J. M., Davis, D. D., Liu, S. C., Newell, R., Shipham, M., Akimoto, H., and McNeal, R. J.: Overview of PEM-West A Result, URL http://www-gte.larc.nasa.gov/pem/pema_rslt.htm, (assessed in January 2005), 1991.

Huebert, B. J., Bates, T., Russel, P. B., Shi, G., Kim, Y. J., Kawamura, K., Carmichael, G., and Nakajima, T.: An overview of ACE-Asia: Strategies for quantifying the relationships between Asian aerosols and their climatic impacts, J. Geophys. Res., 108(D23), 8633, doi:10.1029/2003JD003550, 2003.

Jacob, D. J., Davis, D. D., Liu, S. C., Newell, R. E., Huebert, B. J., Anderson, B. E., Atlas, E. L., Blake, D. R., Browell, E. V., Chameides, W. L., Elliott, S., Kasputin, V., Saltzman, E. S., Singh, H. B., and Sze, N. D.: Transport and Chemical Evolution over the Pacific (TRACE-P): A NASA/GTE Aircraft Mission, URL http://www-gte.larc.nasa.gov/trace/tracep.html, (assessed in January 2005), 1999.

Kang, C. M.: Characteristics of the Fine Particles and Source Ap- portionments using the CMB model in Seoul Area, Doctoral dissertation, Konkuk University, Seoul, Korea, 2002.

Kim, E., Larson, T. V., Hopke, P. K., Slaughter, C., Sheppard, L. E., and Claiborn, C.: Source identification of PM2.5 in an arid Northwest U.S. City by positive matrix factorization, Atmos. Res., 66, 291-305, 2003.

KME (Korean Ministry of Environment): Long Range Transport of Toxic Trace Substances: Identification and Impact Analysis Measurement \& Analysis of Aerosol and Hazardous Substances (in Korean), 11-1480083-000142-14, 87-136, 2004.

Lee, E., Chan, C. K., and Paatero, P.: Application of positive matrix factorization in source apportionment of particulate pollutants in Hong Kong, Atmos. Environ., 33, 3201-3212, 1999.

Mamuro, T. A. and Mizohata, T. K.: Elemental Compositions of Suspended Particles Released from Various Boilers, Annual Report of the Radiation Center of Osaka Prefecture, 20, 9-17, 1979a.

Mamuro, T. A. and Mizohata, T. K.: Elemental Compositions of Suspended Particles Released from Iron and Steel Works, Ann. Rep. Radiat. Center of Osaka Prefecture, 20, 19-28, 1979b.

NIER (National Institute of Environmental Research): Study on long-range transport of air pollutants in Northeastern Asia (III) (in Korean). Report to National Institute of Environmental Research, Korea, Report No. BSG557-6191, Korea Institute of Science and Technology, Seoul, Korea, 1998.

Paatero, P. and Tapper, U.: Analysis of different modes of factor analysis as least squares fit problem, Chemometrics and Intelligent Laboratory Systems, 18, 183-194, 1993.

Paatero, P. and Tapper, U.: Positive matrix factorization: a nonnegative factor model with optimal utilization of error estimates of data values, Environmetrics, 5, 11-126, 1994.

Paatero, P.: User's Guide for Positive Matrix Factorization Programs PMF2.EXE and PMF3.EXE, University of Helsinki, Helsinki, 1996.

Paatero, P.: User's Guide for Positive Matrix Factorization programs PMF2 and PMF3, Part 1: tutorial, 2000.

Paatero, P., Hopke, P. K., Song, X. H., and Ramadan, Z.: Understanding and controlling rotations in factor analytic models, Chemometrics and Intelligent Laboratory Systems, 60, 253-264, 2002.

Perry, K. D., Cliff, S. S., and Jimenez-Cruz, M. P.: Evidence for hygroscopic mineral dust particles from the Intercontinental Transport and Chemical Transformation Experiment, J. Geophys. Res., 109, D23S28, doi:10.1029/2004JD004979, 2004.

Polissar, A. V., Hopke, P. K., Poirot, R. L.: Atmospheric aerosol over Vermont: chemical composition and sources, Environ. Sci. Technol., 35, 4604-4621, 2001.

Ramadan, Z., Song, X. H., and Hopke, P. K.: Identification of sources of Phoenix aerosol by positive matrix factorization, J. Air Waste Manage. Assoc., 50, 1308-1320, 2000.

Ramanathan, V., Carmichael, G., Crutzen, P. J., Holben, B., Prather, K., Prospero, J., Savoie, D., and Schauer, J.: Regional AeorosolChemistry-Climate Observatories for the Indo-Asia-Pacific Region, NOAA, Washington, D.C., accepted, 2003.

Small, M., Germani, M. S., Zoller, W. H., and Moyers, J. L.: Fractionation of Elements During Copper Smelting, Environ. Sci Technol., 15, 299-304, 1981.

Song, X. H., Pollissar, A. V., and Hopke, P. K.: Sources of fine particle composition in the northeastern US, Atmos. Environ. 
35, 5277-5286, 2001.

Sun, Y., Zhuang, G., Wang, Y., Han, L., Guo, J., Dan, M., Zhang, W., Wang, Z., and Hao, Z.: The air-borne particulate pollution in Beijing - concentration, composition, distribution and sources, Atmos. Environ., 38, 5881-6004, 2004.

Swietlicki, E. and Krejci, R.: Source characterization of the Central European atmospheric aerosol using multivariate statistical methods, Nuclear Instrument and Method in Physics Research Section B, 109/110, 519-525, 1996.

US EPA (U.S. Environmental Protection Agency): Protocol for applying and validating the CMB model, EPA-450/4-87-010, 1987.

Watson, J. G.: Chemical Element Balance Recetor Model Methodology for Assessing the Source of Fine and Total Suspended Particulate Matter in Portland, Oregon, PhD Thesis, Oregon Graduate Center, Beaverton, 1979.
Watson, J. G., Chow, J. C., Lu, Z., Fujita, E. M., Lowenthal, D. H., Lawson, D. R., and Ashbaugh, L. L.: Chemical Mass Balance source apportionment of PM10 during the Southern California Air Quality Study, Aerosol Sci. Technol., 21, 1-36, 1994.

Watson, J. G., Robinson, N. F., Lewis C., and Coulter, T.: Chemical mass balance receptor model version 8 (CMB8) user's manual, US EPA/DRI, 1997.

Watson, J. G., Robinson, N. F., Fujita, E. M., Chow, J. C., Pace, T. G., Lewis, C., and Coulter, T. L.: CMB8 Applications and validation protocol for PM2.5 and VOCs, Desert Research Institute Document No. 1808.2D1, 1998. 